\title{
Housing policy retrenchment: Australia and Canada compared
}

\section{Tony Dalton}

\author{
Australian Housing and Urban Research Institute Centre \\ School of Social Science and Planning \\ RMIT University \\ Melbourne \\ Victoria \\ Australia \\ e-mail: tony.dalton@rmit.edu.au
}

\section{Introduction}

Housing policy has declined as a policy priority relative to other areas of policy making in many western countries. This housing policy retrenchment has happened at the same time as the need for affordable urban housing has grown because of increasing house prices and rents and greater income inequality. This retrenchment has been pronounced in the mass home ownership Anglo Saxon societies. It is important to ask, 'Why has housing policy retrenchment occurred at the same time as accepted measures show increased housing need?' This is a question about housing politics, or the making of housing policy. This paper seeks to understand policy retrenchment in Australia and Canada based on the idea that comparative analyses can deepen explanations of complex social and economic processes.

The paper begins with a presentation of key features of the Canadian and Australian systems of housing provision. Both countries can be described as suburban home ownership societies. They also have large private rental sectors that provide the setting for much new household formation. Many households become owners after renting and saving. However, this pathway into ownership from renting is changing. In both countries there has been growth in the number and proportion of households who cannot purchase and who experience poverty and insecurity, sometimes described as 'increasing housing stress', in the private rental market. Against this background of growing disadvantage housing policy has provided less support for these most disadvantaged households. Supply side policy that directs affordable to low income earners in both countries is virtually dormant and demand side assistance is inadequate. Further, there has been a long term decline in the provision of additional social housing and currently there is almost no growth in the stock. Both societies now plainly exhibit significant levels of urban homelessness. 
Against this background of similarity and difference the paper responds to the question 'Why has housing policy retrenchment occurred at the same time as accepted measures show increased housing need?' by analysing developments at two levels. First, there has been a type of regime change in both countries from Keynesianism to neo-liberalism in the context of the changing global economy that has framed policy making, including housing policy. However, the shift itself does not explain policy change. Explanations of policy change require closer attention to detailed institutional change. This leads to a focus on the way in which housing problems are framed in housing policy. It is argued that Keynesian ideas did not support a well developed theory of the role of housing in industrial societies. Second, the analysis focuses on the development of state agencies and their capacity to shape policy directly and through intergovernmental federalism arrangements. Third broader civil society constituencies that interact with state actors to shape housing policy are discussed.

The argument drawn from this analysis is that groups within the Canadian and Australian states and civil society constituencies, despite considerable evidence about new forms of market failure and increasing levels of housing need, have been largely unsuccessful in converting this research evidence into an accepted policy problem. Instead, the private market continues to provide housing for the vast majority of purchaser and renter households. Processes reviewing and modifying the way producers and consumers in these markets are supplemented remains normal housing policy.

\section{Housing provision in Australia and Canada}

During the late $19^{\text {th }}$ and early $20^{\text {th }}$ both Australia and Canada were confirmed as urban societies. In Australia by 1901 'more than 37 per-cent of the populations of four states were found in their capitals and over one-fifth in the other two' (Neutze, 1977:8). Similarly in Canada 'just over 37 per-cent of the nation's population of 5.37 million lived in urban settlements' (Bourne, 1993:271). During the $20^{\text {th }}$ century the two societies were confirmed as urban societies but also as suburban societies through sustained investment in suburban residential property. Further, in both countries the suburbs increasingly accommodated a wide cross section of the population. Frost (1991:22), who includes many Australian and Canadian cities in his 'New Urban Frontier' category, describes the rapid urban growth which began in the late $19^{\text {th }}$ century ${ }^{1}$.

A signal feature of the New Urban Frontier was that the opportunities for suburbanisation spread from the elite to society's lower ranks at an extraordinarily rapid rate. The preference for living in a suburban setting was perhaps no more widespread than in other Anglo-Saxon cities, but was a more realisable goal. In fact, the working classes shared in suburbanisation virtually from the outset, buying or renting housing in modest, but new neighbourhoods.

In both countries, the regional or provincial state and the local state, provided the legal frameworks and the spatial coordination required for the development of the land market and the layout of urban settlements. 
Closely associated with suburbanisation both societies became confirmed home ownership societies through the first half of the $20^{\text {th }}$ century. In 194157 per-cent of Canadian households were owners (Miron, 1988:168) and in 194753 per-cent of Australian households were owners (Jackson and Bridge, 1987:353). In both societies home ownership was preferred. Freestone (1989) sums up the strong association that developed between suburban living and homeownership in Australia.

Almost inseparable from the house-and-garden principle was home ownership. Renting was always contrasted unfavourably, being directly associated with ill-health, moral decline, susceptibility to revolutionary creeds, shiftlessness, and improvidence. [emphasis in the original]

In Canada the association between suburban living and home ownership was remarkably similar (Purdy, 1998, Harris, 1996:chp4, Bacher, 1993:chp2). Harris (1996:96) sums up the nature of the support for suburban homeownership.

In Toronto and across the continent, just about everyone felt that home ownership was a good thing. They believed that it reinforced the independence of the family, encouraging thrift and reducing demands upon the public purse. It was the general opinion that ownership had an especially beneficial effect on workers and immigrants, two groups whose commitment to the status quo could not be taken for granted. Home ownership was supposed to encourage stable work habits while providing workers with a stake in the capitalist system.

In the decades following WWII, a period often referred to as the long boom, Australian and Canadian societies were confirmed as home ownership societies. Working households continued to move into home ownership in a period of rapid population growth sustained by increase in the birth rate and immigration, full employment, particularly full male employment, with rapid rates of economic growth and increasing real wages, and steady growth in the housing stock ${ }^{2}$. Figures 1 and 2 present a picture of remarkable similarity in the pattern of change in the rate of owner occupation in the post WWII period. In both countries the state through both central and provincial governments further developed and extended their support for the production, financing and purchase of owner occupied housing. Throughout the post war period there have been many policy changes. 


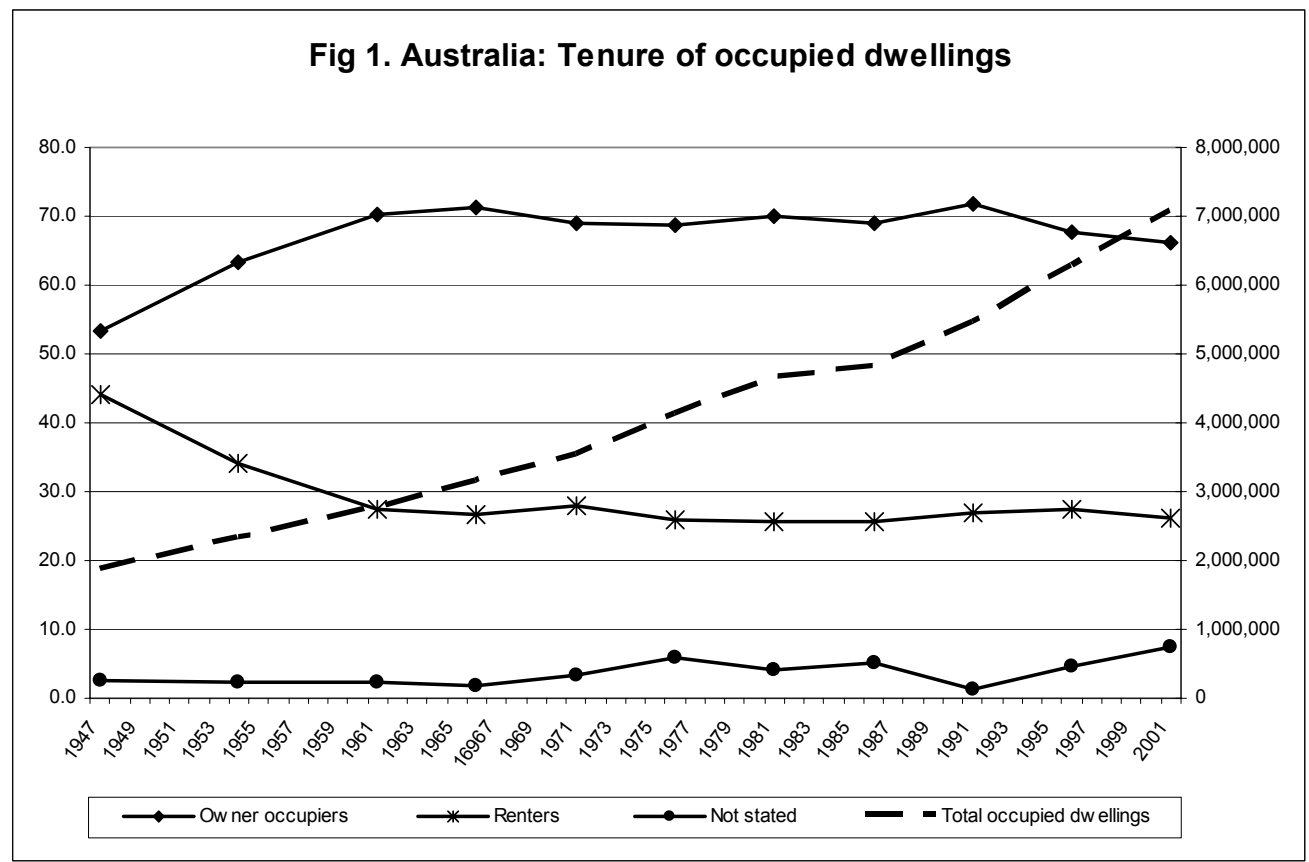

Source: Jackson and Bridge (1987) and ABS 1991, 1996, 2001 Census

In this context the level of ownership in Australia rose particularly rapidly from 53 per-cent in 1947 to 71 per-cent in 1961 and then to 74 per-cent in 1986. Perhaps most significantly in the post WWII decades a significant proportion of low income households became owner occupiers. Beer (1993:147) described the situation in these terms 'In Australia, home ownership is the tenure of all classes of people: the wealthy, the middle class and the working class'.

In Canada the increase in the rate of homeownership was rapid but not quite as great as in Australia. It increased from 53 per-cent in 1941 to a high of 66 per cent in the period 1956-60 before declining to a level of around 62 per-cent. Since the late 1980s it has increased to just over 63 per-cent. For Canada Steele (1993:41) points to a similar pattern access across the income range with 'a dramatic jump in the urban homeownership rate in that decade [1941-51, that] established home ownership as the urban norm and had a major impact on the overall rate for Canada'. She also notes how 'home ownership among traditional households has continued to rise since 1951 '. 


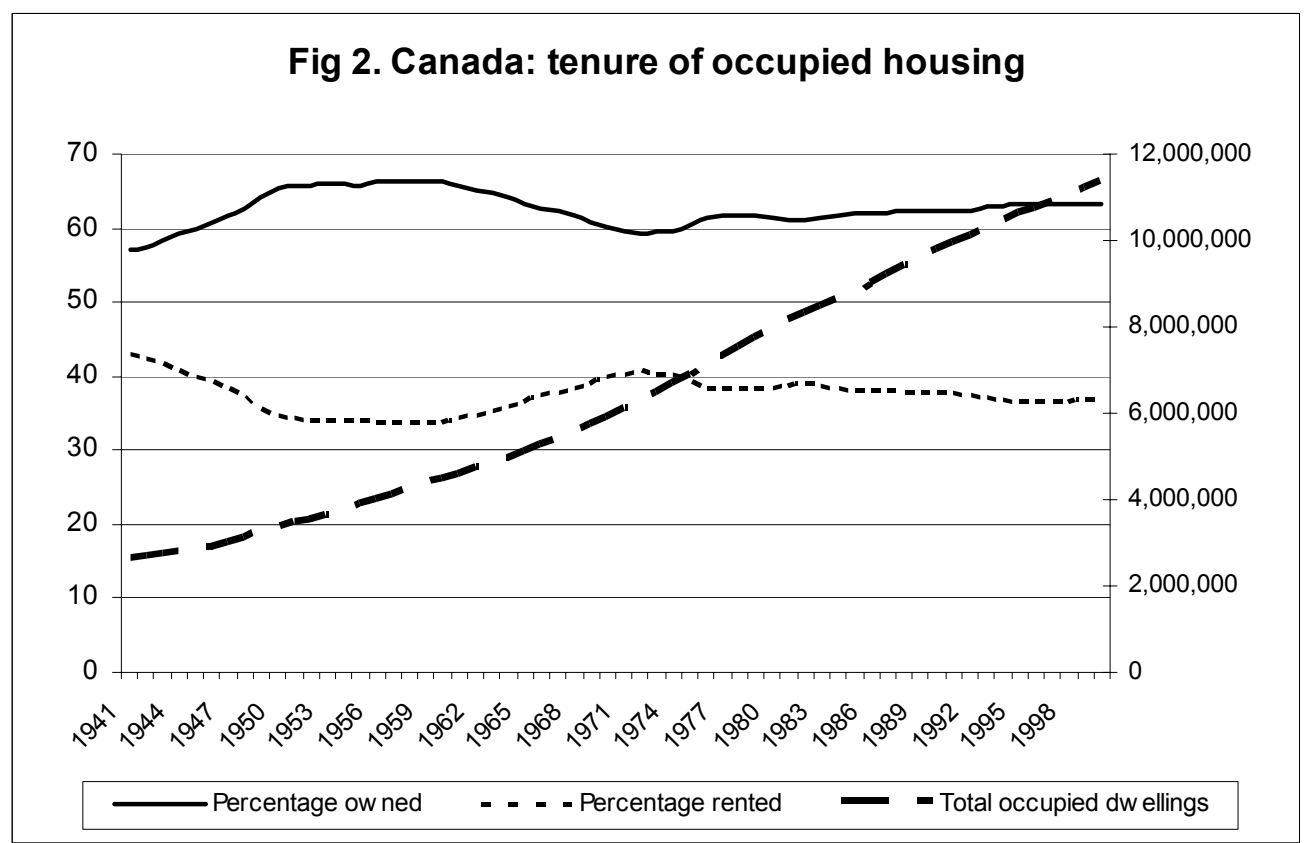

Source: Statistics Canada, Table 030-0001, Housing stock, dwelling units by type of dwelling and tenure

Alongside this focus on the production and financing of home ownership limited social housing programs were established in the post war period, albeit at different times and in different circumstances. In both Canada and Australia social housing is about five per-cent of households or about one fifth of all rental households. However, perhaps more significantly this form of housing is declining as a proportion of all housing.

In Australia social housing is overwhelmingly public housing and is provided by state government agencies, commonly referred to as state housing authorities (SHAs). SHAs became major suppliers of rental housing in the post WWII period and are an example of dirigiste state action. In 1945-46 public housing completions were 23 per-cent of all dwelling completions, a decade later in 1955-56 were 20 per-cent and other decade later in 1964-65 were 14 per-cent. By 1966 public housing constituted 8 per-cent of the total stock of occupied dwellings (Jones, 1972). Until the mid 1950s public housing was providing housing to male workers their spouses and children close to new manufacturing industries. From the mid 1950s a proportion of the housing replaced inner city 'slums' in the inner city areas of metropolitan cities, especially in Melbourne and Sydney. As Figure 3 indicates SHAs were major providers of new housing for nearly three decades. It is clear that this role became more uncertain from the mid 1970s as there were greater oscillations in the number of dwellings being produced. It is also clear that very little is now being added to the total stock of public housing. Indeed recent research (Hall and Berry, 2004) documents a decline in stock numbers from 380,000 to 375,000 dwellings. 


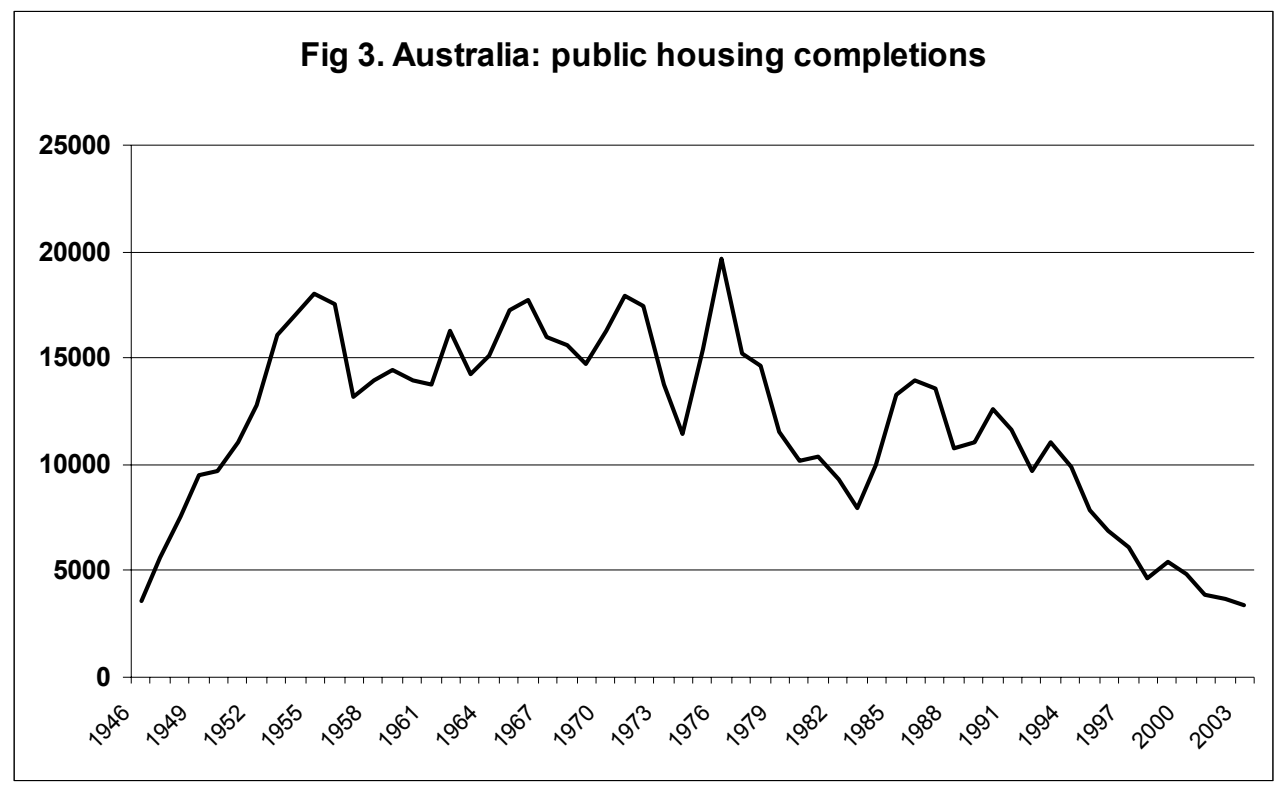

Source: Jackson and Bridge (1987), Jones (1972), ABS Series 87520 Table 23c. Number of Dwelling Unit Completions, Public

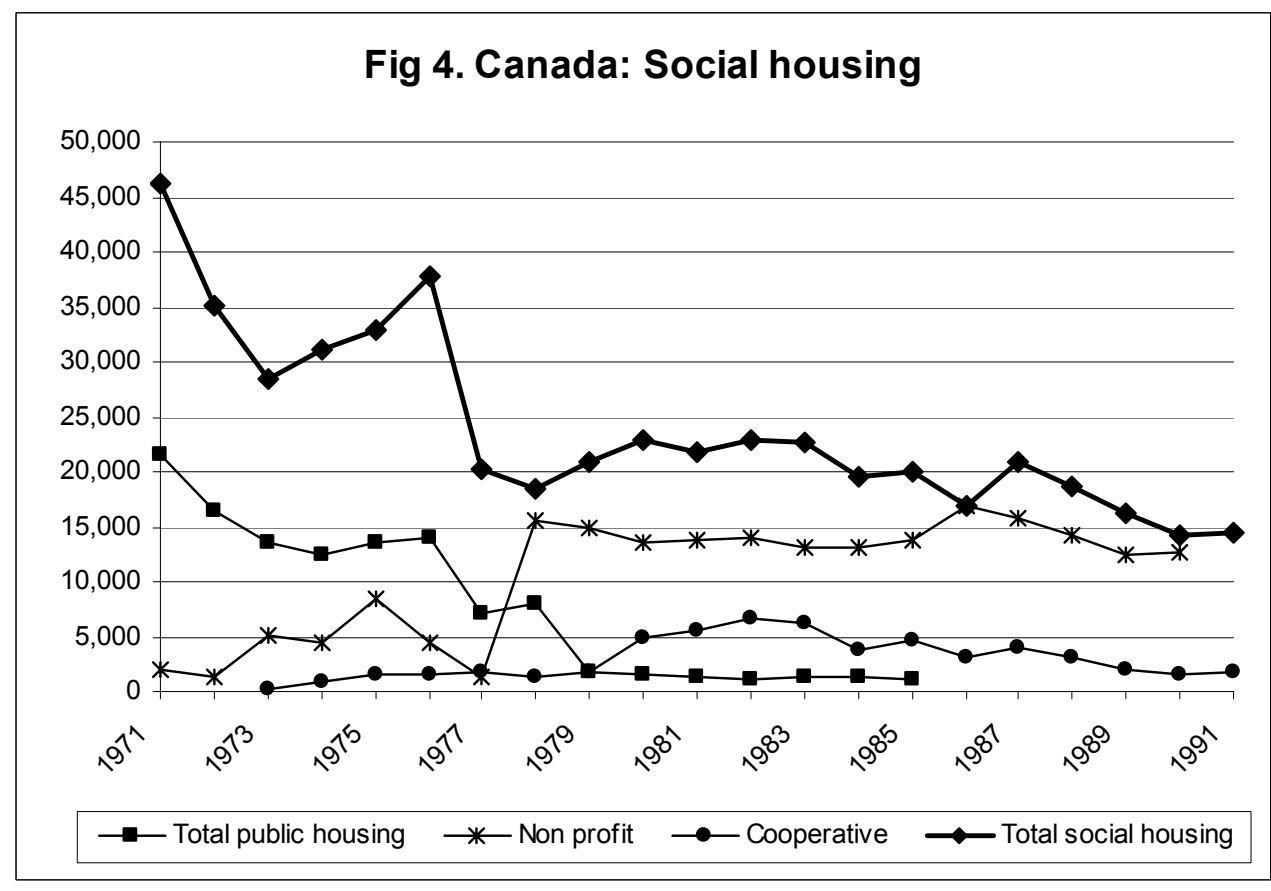

Source: Fallis (1994) from Table: 11.1 Annual Authorised Rental Assistance Units

In Canada the timing and manner of social housing provision was different. In the immediate post WWII period very little public housing was built. By 1960, depending on how it was counted, there were only between 10,000 and 12,000 public housing units and another 5,000 'limited dividend' rental housing units, a type of quasi public housing (Rose, 1980:36). This was a lot less than the 184,000 that had been built in Australia. The growth in Canadian social housing came later following amendments to the National Housing Act and led to a larger public housing program primarily in established metropolitan areas through large scale redevelopment 
programs initiated by provincial governments. Following this initial period of public housing development the provision of Canadian social housing is institutionally more complex than Australian social housing. As Figure 4 indicates, the provision of public housing declined during the early 1970s, while non-profit rental housing associations increased their housing stock using central and provincial government grants and loans. Rental cooperatives also feature in the provision of social housing from the early 1970s and expanded their role in the 1980s.

Both the focus on home ownership and social housing programs should be seen as a part of an overriding policy objective of increasing the overall housing stock. As figures 1 and 2 demonstrate the post war period in both countries has seen a steady increase in the total housing stock. In Canada it has increased from 2.6 million to 11.4 million in the period 1941-2000 and in Australia it has increased from 1.9 million to 7.1 million in the period 1947-2001. Throughout this period this has led to a focus by policy makers on housing production measured by starts and completions indicators and helps to explain some of the history of the constant change in policy and programs in both countries. Figures 5 and 6 illustrate the volatile history of housing starts in both countries and some of the policy program changes that have sought to influence housing production activity.

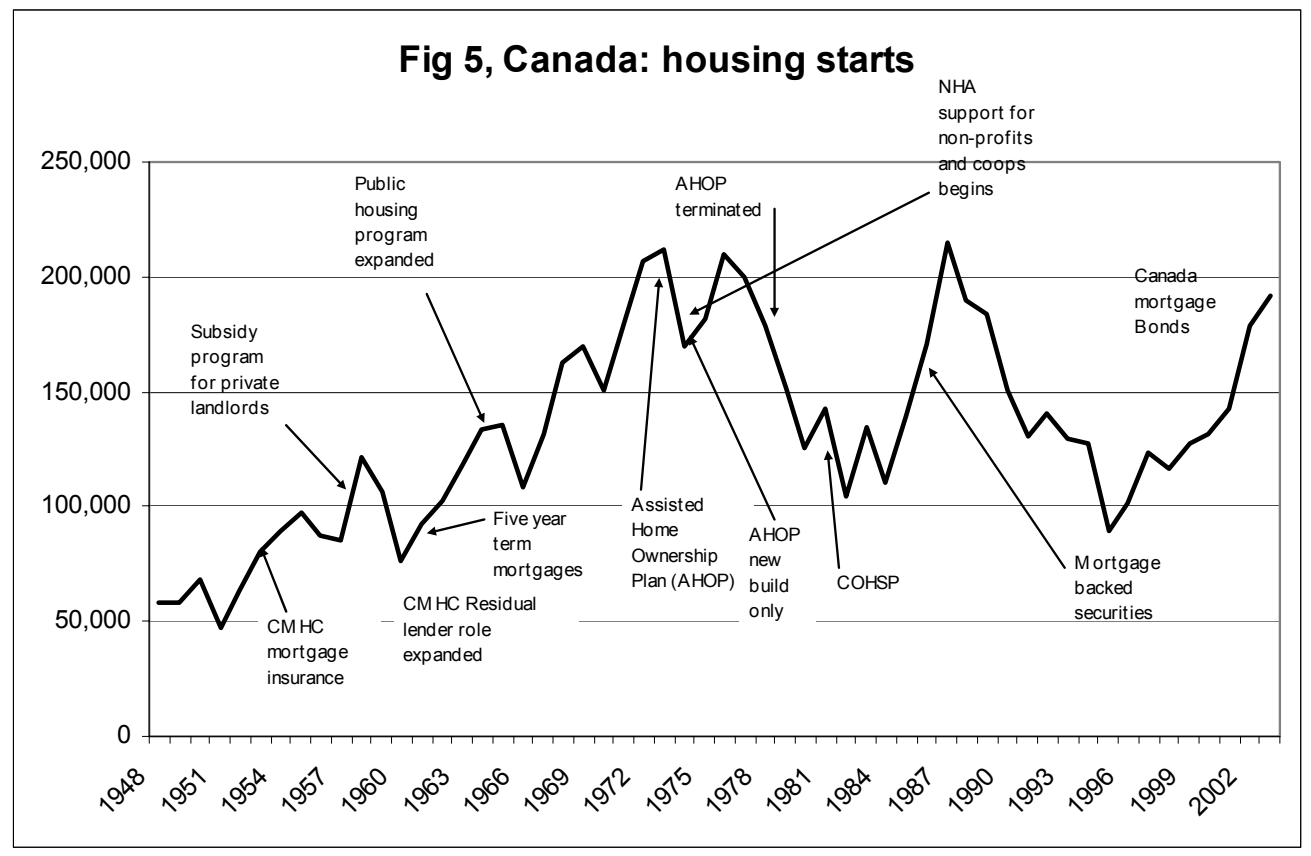

Source: Statistics Canada Table 027-0001: Housing starts, under construction and completions 


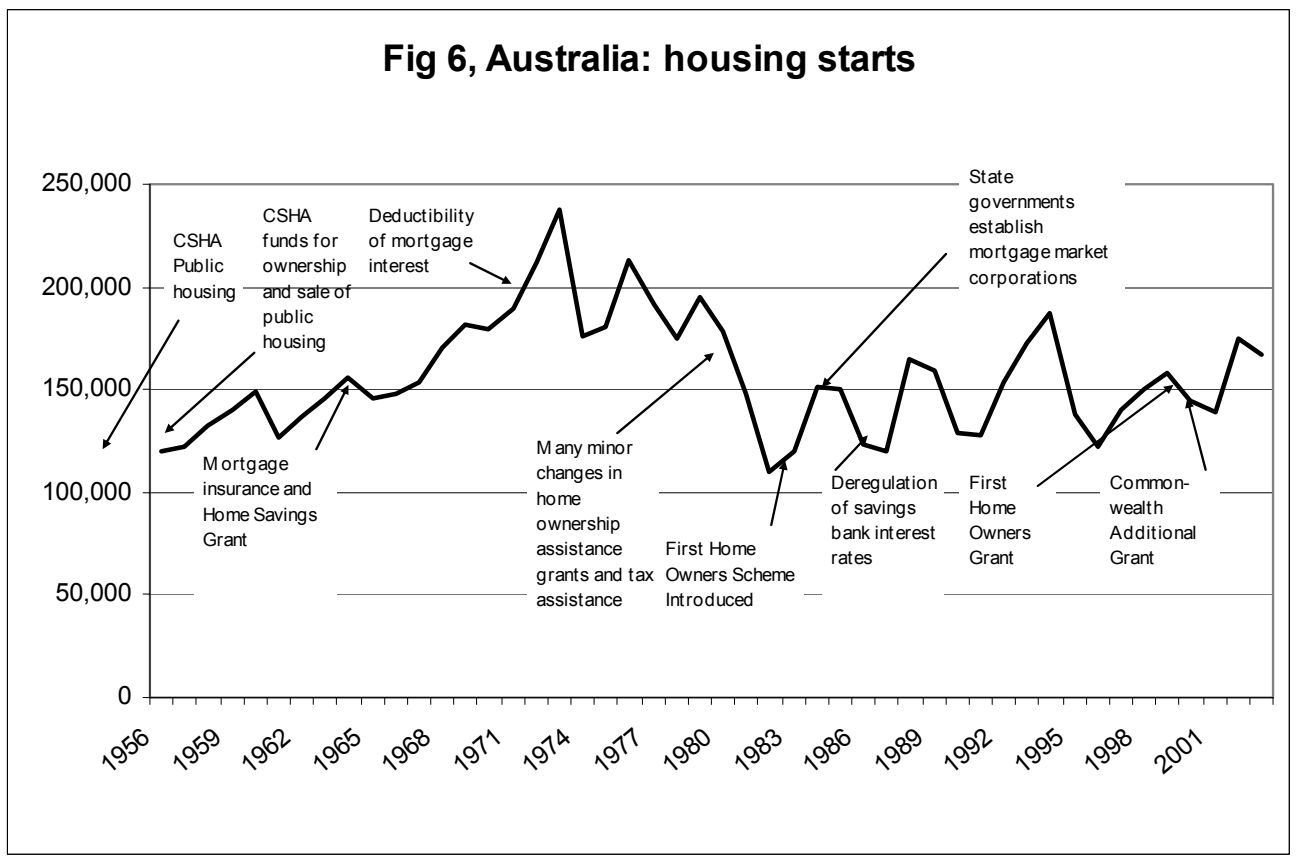

Source: ABS, Series 875001a, Table 1A Dwelling Unit Commencements, Australia

Both societies became confirmed mass homeownership societies in the post war period. However, there are now indications that beneath the overall trend lines there have been some significant changes in the typical housing careers of a significant proportion of low income households.

In Australia this is most evident in changes within the private rental market where low income households have experienced declining affordability (Yates, 1998, Yates, 2000, Yates and Wulff, 2000). In the past the private rental market has been a staging post for a large proportion of tenant households but the pattern of movement into owner occupation has been changing. This is evident in a number of trends including, the increase in average length of time households live in private rental housing before purchasing and the average ages of these households; a faster rate of growth of rental households compared to households in other tenures; growth in the numbers of households in all income categories (low - high) living in the private rental market; growth in the proportion of low income and low-moderate income categories in the private rental market; growth in the number of people moving from homeownership to rental because of household breakdown or mortgage default - 'returners'; decline in low cost rental stock and growth in stock used by low-moderate to high income groups; and cheaper rental stock is being 'crowded out' by higher income rental households. The resulting national shortage of low income rental housing now estimated to be at least 50,000 rental units. Further, current patterns of investment in the sector hold no prospect of sustained investment in private rental housing that will result in increased supply (Berry, 1998).

In Canada there has been a similar decline in affordability within the private rental market particularly for very low income households (Pomeroy, 2001) (TD Bank Financial Group, 2003). Similar to Australia declining affordability is associated with shortages in the supply of affordable dwellings (Crook, 1998). The TD Bank Financial Group (2003:8) describes the 
situation in these terms: 'there are not enough dwellings available for Canadian households today at a price they can afford on their current income...Canada's stock of rental housing - which is the segment of the market wherein those in core need are largely situated - has been shrinking for years...what's worse, the lower end of the market - which is to say, affordable rental housing, as measured by rent levels - has been particularly hard hit in most of Canada's major cities'. Like Australia current new investment is not providing rental housing that low income households can afford (Crook, 1998). This decline in affordability for low income households has developed notwithstanding significant income security programs in both Australia and Canada. In Australia the payment is called Rent Assistance and the total cost is about $\$ 1.7$ million paid directly by central government. In Canada the provinces are primarily responsible for social assistance including the shelter component. In the mid-1990s expenditures are estimated to have been $\$ 5$ billion per year (Canada Mortgage and Housing Corporation, 2002).

There are at least three underlying socio economic trends behind growing levels of disadvantage experienced by low income private tenants in both countries. First, there is income inequality. In Australia income inequality has grown. Amongst a group of 11 rich nations Australia is one of the more unequal with a ranking of 8. In the decade 1985-94 it became more unequal (Gini coefficient increase from 0.295 to 0.317 ). In Canada income inequality did not change (Gini coefficient of 0.286 ) and relative to other countries it became less unequal by moving from 7 to 6 in the rankings (Smeeding, 2000). Second, although there has been significant employment growth in both Canada (Burke and Shields, 2000) and Australia (Campbell, 1997) significant restructuring has resulted in greater levels of income inequality and insecurity particularly in Australia. Both of these labour market outcomes are reshaping the traditional renting to owner housing career. Third, there has been very substantial medium term increases in house prices in both countries particularly in the large metropolitan cities where the majority of the populations of both countries live (Carter, 2004) (Berry and Dalton, 2004).

\section{Regime change}

The Canadian and Australian economies have long had some similar features. During the post WWII decades both nations further entrenched their reliance on commodity exports and protection for domestic secondary industries as a basis for economic growth and full employment policy (Bell, 1997:ch6) (Jenson, 1989). Also policy makers were guided in how they sought to manage their economies by using Keynesian economic thought (Watts, 1987). There were differences in the institutional arrangements associated with this. In Australia it was an element in what is commonly referred to as the renewal of the 'Australian settlement' which was embedded in central state institutions as a result of earlier class based politics. In Canada it seems that the Keynesian paradigm was less embedded in the policy making arrangements in the post WWII period (Jenson, 1989, 1990, Bradford, 2000). Bradford (2000:58) describes it as 'technocratic Keynesianism' which was more a bureaucratic rather than a political project'.

By the mid 1970s both countries were confronted, as were all western developed countries, by exogenous shocks of the 1970s. For Canada and Australia they stemmed from increased oil prices, reduced commodity prices, and the unilateral abandonment by the USA of the fixed 
currency exchange rate mechanism. In all countries these shocks presented a challenge to normal politics.

There was a clear break with the orthodox politics which had been established after 1945, in which most centre, right and social democratic political parties shared many common assumptions about he appropriate relations between the state and the market and the necessity for the mixed economy of welfare capitalism. In contrast after the mid-1970s, the ground began to shift as governments tried and failed to sustain the trinity of rising incomes, low unemployment and expanding welfare provision (Harloe, 1995:380).

In Canada and Australia this change in politics became apparent in two institutional changes: the ideas underpinning economic policy making; and the greater salience of economic policy making elites within both the Australian Canadian states. Both are important for understanding the context for the making of housing policy.

In both countries the seeming impossibility of using Keynesian economic ideas to deal with changing economic conditions, particularly the high and persistent rates of inflation and unemployment, established a context for a paradigm shift in economic thinking (Whitwell, 1986:264, Capling and Galligan, 1992, McQuaig, 1999:ch3, Rice and Prince, 2000, Bradford, 2000:63). This is the context in which neo-liberal economic thought was increasingly embraced within universities, the media and government which 'at its most basic its political message favours a minimalist form of government' (Toohey, 1994:3). In both countries this led to considerable efforts to reduce public expenditure across a wide range of programs. Although how these ideas were actually embedded in the practices of policy making varied (Mishra, 1990).

This paradigm change in economic thought in Australia and Canada was associated with two significant changes in policy making arrangements within both states. First, central state elites centralised the power that had been diffused during the period of sustained economic growth in the post-WWII period by groups in policy and issue networks (Cerny, 1990:200, Saward, 1997, Wanna, 1997). Central state actors, while claiming the 'future of the national economy' is at stake, reinforced their structural power to make economic policy. In both Australia and Canada this was achieved through measures, including strengthening first minister agencies, establishing a clear hierarchy amongst ministers and establishing an Expenditure Review Committee (Saward, 1997:29). More broadly central powers were used to further change federalism arrangements through reducing the share in the flow of resources to provincial and state governments (Inwood, 2000, Mathews and Grewal, 1997).

Of course the relationship between ideas and state reorganisation and policy outcomes is always contingent. Figure 7 presents an overview of the outcome for both countries and shows that despite the dominance of neo-liberal thought social expenditure actually grew and became more significant in the economy and societies of both countries. In Canada the growth was 4 per-cent of GDP and in Australia it was 5 per-cent. In both countries social expenditure as a proportion of GDP has been very similar since the mid 1990s including the decline in 1997 and 1998. However, the lines on the Figure 7 do indicate differences in the way budget policy has been 
formed in relation to the economy. Canada stands out, where it seems that policy makers steadily reduced social expenditures as a proportion of GDP from 21.3 in 1992 to 17.3 in $1998^{3}$. Overall these trend lines further confirm Wanna's (1997:173) conclusion for Australia, Canada and other OECD countries 'that targets are frequently beyond the effective control of the core executive; and success in achieving targets depends upon a vast range of contingencies'.

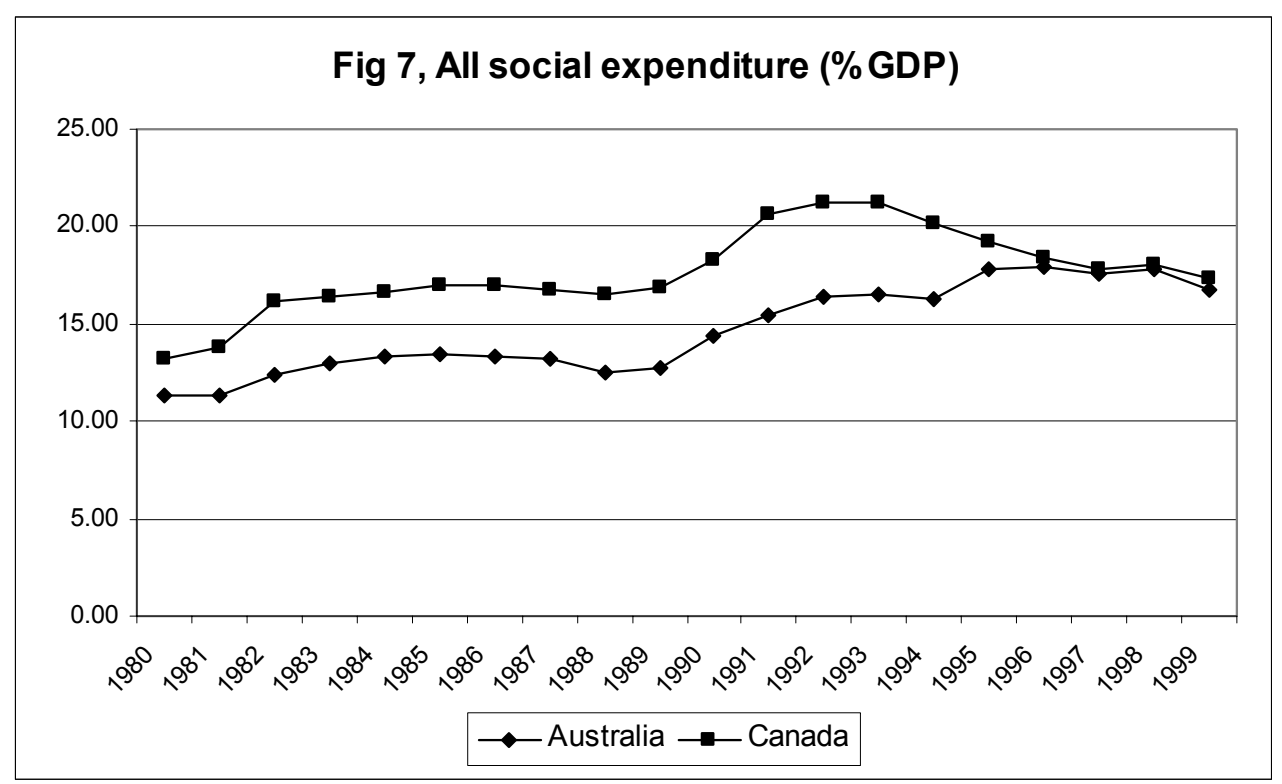

Source: OECD (2000)

The effect of this centralisation and change in economic policy discourse on housing policy is evident in both Australia and Canada. In Australia it resulted in a distinct reduction in the veneration of the idea of 'homeownership' that so pervaded the post war political discourse. Senior officials and politicians openly canvassed the possibility of decline in homeownership rates. The housing commodity was one commodity among many and there was no need to see it as particularly special. Accompanying this economic policy makers were prepared to champion other priorities at the expense of owner occupation. The most significant measure was the dismantling of the protected circuit of finance directed to owner occupiers by deregulating housing interest rates, privatisation of the government owned mortgage insurance company and sale of the central state owned bank (Dalton, 2002). Also the introduction of compulsory contributions to occupational superannuation that reduced the saving capacity of young households was significant (Senate Select Committee on Superannuation, 1994). Reductions in public housing expenditure also continued and the level of targeting to very low income households continued. However, compensatory welfare payments increased including housing related payments (Rent Assistance) increased based on the assumption that the rental market would supply the necessary housing (Hall and Berry, 2004).

In Canada the central state has reshaped its presence in the housing system differently. Unlike Australia it maintained a role in supplementing housing finance market operations, principally by keeping the Canada Mortgage Housing Corporation in public ownership. It has continued a major presence in mortgage insurance, the secondary mortgage market and more recently it sought to improve the supply of low-cost mortgage funds by issuing Canada Mortgage Bonds. 
However, its withdrawal from support for social housing provision is similar to Australia. The federal government has 'maintained a position that it will not entertain any new initiatives that involve ongoing subsidies'. It is only prepared to enter into a very limited program of capital assistance for additional social housing (Pomeroy, 2003).

\section{Framing the housing problem}

There has been a regime change in both countries from Keynesianism to neo-liberalism that has framed policy making, including housing policy. However, this shift on its own does not explain housing policy change. It is important to be more specific about how features of economic and social life become included and excluded as policy problems and objects of state policy attention. In order to understand housing policy change it is necessary to consider more closely what ideas about housing underpinned post WWII housing policy. This requires a focus on the Keynesian economist and social liberal reformers. In both countries these groups brought analyses of housing problems into the post war reconstruction public policy processes. What stands out is the different ways in which these ideas related to each other in the two countries and informed policy outcomes.

In Australia this was done through the Commonwealth Housing Commission (1944:8) that stated that 'we consider that a dwelling of good standard and equipment is not only the need but the right of every citizen'. It recommended a social liberal vision for post War housing including national town and regional planning, controls on land development, reorganisation of the housing industry, new housing standards, new housing designs, slum clearance and community facility provision and public housing provision. In Canada in the same year the Advisory Committee on Reconstruction (1944) set out a similar analysis and recommended an action program (Bacher, 1993:ch6). Both committees drew on the accumulated social liberal housing and urban planning discourse that stretched back to the end of the $19^{\text {th }}$ century in their own countries and the UK.

Ultimately the analysis and action programs were largely unsuccessful in redefining how housing and broader urban development issues should be included on policy making agendas. In Canada this report, along with the Marsh (1943) report on social security, were defeated in the central state policy making processes. It confirmed the subordination of social policy to larger economic and political considerations (Watts, 1987:39). More specifically in housing program terms it resulted in the public housing program being largely still born. As noted above central government support for public housing in the first decade after WWII was minimal. In Australia similar policy processes shore the Commonwealth Housing Commission report of its broader urban planning argument and recommendations but did accept the argument for support of a public housing program. The result was the dirigiste public housing program described above and illustrated in Figure 3. This significant difference in housing program outcomes should not however be seen as a triumph of social liberalism. Instead it should be placed in the context of the Keynesian discourse on housing policy.

This discourse had three discernable elements which are remarkably similar in Canada and Australia. First, there was the focus on the flow of resources into the housing system. In both countries officials analysed the flow of credit into housing which in turn became one of the flows 
that central banks considered when they were developed in Canada and Australia during the late 1930s (Belec, 1984) (Linklater, 1992). As the Royal Commission appointed to inquire into the Monetary and Banking Systems at present in operation in Australia (1937:252) noted 'the system which we contemplate is one in which a strong central bank regulates the volume of cedit, and pays some attention to its distribution'. Second, there was the relationship of housing to employment policy (see for an early Canadian contribution Firestone (1943)). The defining text here was the work of Professor R.I. Downing, a Melbourne University Keynesian economist, had set out the case through the International Labour Office (1948). Translated into the Australian context he wrote 'if houses go on being built, a vital section of total effective demand will be stabilised and the problems of full employment correspondingly simplified (Downing, 1948). Third, there was the development of a technical discourse on housing land and production costs (Mendelsohn and Hamilton, 1948).

Placed in this context the Australian public housing program is more an outcome of Keynesian post war economist judgements in the Department of Post War Reconstruction. They judged that the Australian central state, through an intergovernmental agreement, which became known as the Commonwealth-State Housing Agreement (CSHA), could increase its level of control over the allocation of credit to housing in the context of many competing demands; more carefully relate housing to employment; and monitor the costs of land and housing production. Through a process of negotiation with state governments the first of these agreements was established in 1945. Each of the states went on to fully develop their nascent SHAs that managed their public housing construction programs(Jones, 1972). Because of a longer and more established Australian tradition of large scale statutory authorities, some times described as 'state socialism' or 'socialism sans doctrine', there was broad initial acceptance of the measure. Further, this program was serviced other Keynesian policy objectives, the development of secondary industry. Through these authorities state governments could ensure that public housing provision supported industrial development by making agreements with companies, especially branch plants of overseas multinationals (Berry, 1988).

In Canada the Canadian Keynesian economists made a decision that they could achieve the same economic outcomes through other means. Perhaps less influenced by social liberalism, they judged that public housing supply side measures set out by the Advisory Committee on Reconstruction (1944) were not necessary. Suasion of private credit through the insurance and banking system and then a program of mortgage insurance would be sufficient to be able to satisfy demand for housing credit and manage employment and economy wide aggregate demand. This was a judgement, as Bacher (1993) argues, that they could 'keep to the market place'. This position was challenged by social liberals. They continued to produce evidence that very low income Canadian households were excluded from homeownership and continued to rent expensive and unsatisfactory housing (Carver, 1975) (Wolfe and Jay, 1990). By the mid 1964 this was one of the influences leading to the National Housing Act amendments and the expansion of the public housing. However, this and other changes in housing policy through the late 1950s and 1960s were closely aligned to Department of Finance use of housing starts as a means for managing aggregate demand (Dennis and Fish, 1972). Fallis (1994:376) in his review of housing policy, even after the very significant social housing program developments of the 1970 s and 1980s, emphasises the strength of this association. 
I would argue that the dominating forces shaping federal housing policy are federal decisions regarding monetary and fiscal policy... The federal government has always used housing programs as instruments of fiscal policy: when stimulus is desired new programs are begun and more funds are allocated to existing programs; when restraint is desired housing programs are cancelled and allocations to existing programs are reduced.

In sum, in both countries a post WWII housing policy discourses developed that informed housing policy. Housing investment became an investment sector included in macro economic resource allocation calculations. However, the discussion of housing by economists did little more than elaborate on ways to factor housing into Keynesian aggregate demand and supply analysis aimed at maintaining industry stability and full employment. Broader distributional issues were not considered in the same systematic way. The social liberals sought to incorporate a social policy perspective focussing on those who continued to be excluded but were largely unsuccessful. However, their arguments only tended to be considered when aggregate supply and demand issues became unbalanced and became a public issue.

In the 1970s there was a sense in both countries that a new social liberal discourse might overcome the narrowness of Keynesian economic housing analysis. Academics entered the field and prepared new analyses and more left of centre governments in the early 1970s supported new inquiries into housing and broader urban affairs. The amount of discussion and debate about housing policy increased considerably. Much of it started with the observation that the cost of housing for a significant proportion of households led to poverty. This led to more thorough going analyses of distributional issues and the broader role of housing in the development of social and economic relations. In Australia for example three contributions (Comission of Inquiry into Poverty, 1975, Priorities Review Staff, 1975, Flood and Yates, 1987) presented an analysis that the subsidy system was skewed towards owner occupiers, especially towards owner occupiers with the most expensive housing and highest incomes. Similarly in Canada there were analyses such as those by Wheeler (1969), Lithwick (1970), Dennis and Fish (1972) and Rose (1980) that broadened the social liberal analysis considerably. However, it is also important to note important unresolved tensions in social liberal housing discourse, such as targeting and social mix, taxation, and over-investment which perhaps undermined the impact of social liberal housing discourse.

By the late 1970s and early 1980s the debate changed. This was a period in which neo-liberal ideas were being widely used to understand high rates of inflation and unemployment and new demands on state budgets (Cockett, 1995). In both Canada and Australia key actors in both central states were instrumental in sponsoring highly influential official inquiries that supported neo-liberal policy solution. In Australia the most influential of these was the Committee of Inquiry into the Australian Financial System (Campbell Inquiry) (1981:1) that opened with the doctrinal statement; 'The Committee is of the view that the most efficient way to organise economic activity is through a competitive market system which is subject to a minimum of regulation and government intervention'. Further, the inquiry process, according to one observer, was conducted as a national 'teach in' (Pauly, 1987). In Canada the Royal Commission on the Economic Union and Development Prospects for Canada (Macdonald Commission) (1985) promoted similar neo-liberal agenda. Bradford (2000:72) argues that this was the agenda that the 
Department of Finance was able to progressively put in place and by the mid 1990s reduce public expenditure. Figure 7 certainly indicates that this was the time that social expenditure as a share of GDP began to decline.

'Why has housing policy retrenchment occurred at the same time as accepted measures show increased housing need?' This section of the paper has answered this question by focussing on the ideas that have been used to guide post war housing policy. In summary I have argued that Keynesian economics in both countries developed a very limited analysis of housing provision and social liberal discourse was not institutionalised. There was a period during the late 1970s and 1980s when housing policy discourse was significantly expanded by substantive social liberal contributions. However, there were unresolved tensions amongst social liberals. Further, this more complicated analysis stood in contrast to the much more apparently simple and coherent neo-liberal analysis. This is the context within which neo liberal policy ideas have been ascendant and social liberal arguments marginalised. It is a form of analysis that does not recognise the development of new and enduring forms of disadvantage in housing markets that are emerging with changing forms of investment in housing markets and new forms of labour market and income inequality.

\section{State arrangements and housing policy}

Accounts of policy processes and outcomes must also consider the detailed institutional arrangements of agencies involved in intervening in housing systems. Within all states particular agencies support markets and supplement the capacity of some actors through inter-agency arrangements and formal legal systems of administration. Therefore, an account of the way in which housing policy is made must include state agency administrative arrangements and the efforts of actors to reshape them, abolish them and so on. This proposition comes from the argument that the detailed institutional arrangements and the bureaucratic and professional capacities of state agencies are important factors in explaining the way in which policy ideas are proposed and responded to within the interstices of the state (Mahon, 1977, Franzway et al., 1989, Hall, 1989, Jessop, 1990). Discussion of these capacities perhaps helps to further answer the question posed in this paper about why there has been policy retrenchment at a time when there has been an increase in housing need.

In both Australia and Canada housing agencies developed at both a central and provincial/state level with capacities to run housing programs, prepare analyses and develop housing policy advice. Table 1 presents a list of the housing agency arrangements for both countries for the immediate post war period and for the most recent period. There are some remarkable similarities and differences in the development of these agencies which can be appreciated by discussing arrangements at the central and provincial/state level in each of the two periods and the relations between the two levels. 
Table 1: Housing agency arrangements in the Australian and Canadian states

\begin{tabular}{|c|c|c|}
\hline \multicolumn{3}{|c|}{ Keynesian period } \\
\hline & Central & Provincial/state \\
\hline Australia & $\begin{array}{l}\text { Department } \\
\text { Branch/division in ministry (1945 - ) } \\
\text { Dep't of Urban and Regional Development (1972-75) } \\
\text { Statutory } \\
\text { Housing Loans Insurance Corp (1964 -) } \\
\text { War Service Homes Commission } \\
\text { Australian Housing Corporation (1974-75) } \\
\text { Commonwealth Savings Bank } \\
\text { Reserve Bank of Australia }\end{array}$ & $\begin{array}{l}\text { Statutory } \\
\text { State housing authorities eg Victorian Housing } \\
\text { Commission, South Australian Housing Trust } \\
\text { State banks eg State Savings Bank of Victoria }\end{array}$ \\
\hline Canada & $\begin{array}{l}\text { Statutory: } \\
\text { Canada Mortgage Housing Corporation (1946 -) } \\
\text { Department: } \\
\text { Ministry of Housing and Urban Affairs (1971-78) } \\
\text { Bank of Canada }\end{array}$ & $\begin{array}{l}\text { Statutory: } \\
\text { Provincial housing agencies eg Ontario Housing } \\
\text { Corporation, British Columbia Housing Management } \\
\text { Commission }\end{array}$ \\
\hline \multicolumn{3}{|c|}{ Post Keynesian/Neo-liberal period } \\
\hline & Central & Provincial/state \\
\hline Australia & $\begin{array}{l}\text { Department: } \\
\text { Branches in ministries }\end{array}$ & $\begin{array}{l}\text { Department: } \\
\text { State housing authorities in ministries }\end{array}$ \\
\hline Canada & $\begin{array}{l}\text { Statutory: } \\
\text { Canada Mortgage Housing Corporation }\end{array}$ & $\begin{array}{l}\text { Department: } \\
\text { Provincial housing authorities in ministries. } \\
\text { Local government: } \\
\text { Ontario (2001) }\end{array}$ \\
\hline
\end{tabular}

In both Australia and Canada both governments developed central agencies that worked on housing issues in the immediate post war period. However, the way in which they did this was different.

In Australia there was a limited development of central housing policy analysis capacity and little supervision of the CSHA public housing program. This is evident for instance in the assessment of by Sir William Dunk, Chairman of the Public Service Board, who in 1950 described the Housing Section of the Department of National Development as being 'mainly established to police the Commonwealth State Housing agreements, but it also does a certain amount of research on housing, and publishes information on types, costs etc' (Dunk, 1950). In 1954 little had changed when the Minister for National Development, Senator Spooner, complained that 'the staff of my building industry section totals six in all. The result is that the basic information that is needed to evolve a policy is not readily available' (Spooner, 1954). Further, connections between the minister and other agencies, particularly the War Service Homes Commission and the Commonwealth Savings Bank, were limited ${ }^{5}$. The same disconnectedness was a feature of the relationship with the Housing Loans Insurance Corporation when it was established in 1964 following the provision of advice by CMHC officials. It was located in Sydney and its officials had little involvement with Canberra based policy processes. Although the number of housing staff in the Canberra department grew this early focus on housing industry analysis and 'policing' the CSHA changed very little throughout this period. The only aspect that changed was the reorganisation of departments and the move of the housing branch, later to become a division, into many different departments. Further, over the years these departments became to be represented by ministers with less and less status in the ministry.

In Canada the establishment of the Canada Mortgage Housing Corporation in 1946 signalled a different approach. It began as an operational agency through the direct provision of rental 
housing to veterans and then developed an operational housing finance function through direct lending programs and then from 1955 a mortgage insurance program. It also developed program management groups that for social housing. However, what is striking is that the capacity of $\mathrm{CMHC}$ to analyse housing markets seems to have remained limited like the Australian department. Dennis and Fish (1972) presented a description of the CMHC capacity to prepare housing analyses similar to that of Dunk and Spooner when they stated 'It should be noted, however, that until four years [1968] ago there was no Economics Division. Economic research was carried out by two or three men, virtually on the backs of envelopes'. Its real presence was in the development of large program management groups in Ottawa and regional offices in major cities in the provinces. This is in contrast to Australia where the departmental housing group only maintained a presence in Canberra and never established offices in the states. The other stand out feature of CMHC leaders was the way in which they sought to separate themselves from government policy making by choosing a office location in the early 1950s away form Parliament Hill in order to "express the independence of CMHC as a corporate institution that could perform its role best if it was beyond the reach of cabinet ministers and political influences' (Carver, 1975:112).

Both countries towards the end of the long boom both sought to place housing within a larger urban affairs policy context. In Canada this led to the establishment of the Ministry of Housing and Urban Affairs in 1971 and in Australia the Department of Urban and Regional Development in 1972. Both agencies had a view that policy making across most portfolios should recognise urban impacts and be much more coordinated. Housing was a particular focus in both cases. However, the Canadian ministry established a more direct involvement with housing policy and programs although this was often contested by CMHC (Rose, 1980). As Carver (1975:112) notes: 'to be stuck with the model of an insurance company has, in a later period of history, made it very difficult to put CMHC into the context of a Ministry of Urban Affairs'. In Australia the department did not have responsibility for housing policy and programs which remained in the Department of Housing and Construction. It was restricted to managing a number of projects, providing a critique of housing policy and working to establish the ill fated Australian Housing Corporation (Lloyd and Troy, 1981).

The arrangements in the states and the provinces were more alike with the development of large activist housing authorities. In Australia each state established, either just before or after WWII, a housing authority with high levels of statutory independence supported by legislation. In the post war period they became major land and housing developers as was indicated in Figure 3. In effect they became state owned building companies that acquired tracts of land on the fringe of capital cities and in some provincial cities. Later the Victorian and NSW authorities used their powers to acquire inner city land for slum redevelopment. Their objectives were to build as many dwellings as quickly as possible. Although there were some differences between authorities construction professionals tended to become influential in designing the programs and ultimately leading the authorities (Marsden, 1986, Dalton, 1988). Other functions such as tenancy management and maintenance functions tended to become second order priorities. Also these authorities developed a very independent stance in relation to other state government agencies and local government. Consultation around the development of the housing programs was limited. 
This is very similar to the development of Canadian provincial housing authorities that developed their programs in the early and mid 1960s. Dennis and Fish (1972:144-159) in their description of these authorities present an account of centralised authorities focussed on the production of housing and engaging in little consultation. Their description of the Ontario Housing Corporation could as easily be a description of the Victorian Housing Commission. 'The provincial corporation saw its mandate as the immediate production of low income housing units. From the start, the emphasis was placed on unit starts and OHC's relations with municipalities, other departments, and CMHC were very much affected by its perception of its primary purpose'.

The primary difference between Canada and Australia during this period was in the area of intergovernmental arrangements. In Australia there was what could be described as a hands-off approach. Central officials intervened very little in the work of SHAs and established only very minimal reporting requirements (Pugh, 1976). At a government to government level the relationships around housing were in the main multi-lateral through annual conferences of housing ministers. In Canada there was a much more active relationship. CMHC through its regional offices and through its head office were involved through this early period in project by project approvals. This led to extensive bilateral relationships. Associated with this very close attention to detailed program management there is a long history of tension and conflict with provincial housing authorities (Dennis and Fish, 1972).

In the post-Keynesian period there is much that has remained the same and some aspects that have changed at a central level. In Australia central government continues to receive housing policy advice from small groups of officials in ministries now located in two different ministries. One is in the community services ministry with responsibility for the CSHA and an associated set of bilateral performance measures for SHAs. The other small group is in the industry department and continues with traditional housing market analysis. Further, the low ministerial and administrative status of these groups was confirmed.

In this context the central agencies of Treasury and the Reserve Bank of Australia became more powerful. They were the agencies that oversaw the deregulation and restructuring of Australian financial institutions. The Treasury then supervised the sale of the Housing Loans Insurance Corporation to GE Capital. In the current context the central agency that has most to say about housing policy in the Reserve Bank of Australia as it seeks to manage speculative investment flows in the housing sector in a low interest rate environment. In Canada housing policy is similarly dominated by central agencies, the Department of Finance and the Bank of Canada, that have as their main policy objective relating housing markets to broader economic policy objectives (McQuaig, 1999, Mitchell Evans et al., 2000:87). The CMHC in this context has become a much less interventionist agency. Its mortgage business has been corporatised and operates as a largely independent business with reduced scope for cross subsidisation. Further, it has been through a program of capitalising its subsidies to non profit housing agencies. Its support for new social housing, like the CSHA, is providing very low levels of support for new social housing.

At the state/provincial level the principal change has been to the way in which the housing authorities operate. In both countries they have been confronted with how to manage large and 
ageing property portfolios and a virtual cessation of their new housing development role. In Canada this role has been increased by the transfer of responsibility for oversighting the operations of the not-for-profit housing sector from the CMHC to provincial governments. Further, there has been increased targeting of housing to very low income households. This has resulted in the statutory authorities in both countries becoming less independent and more integrated with other state/provincial ministries. In the case of Ontario, the province with the largest social housing stock, operational responsibility has been devolved to the municipal level while the broader policy role remains with the Ministry of Municipal Affairs and Housing.

In sum, the housing agencies that developed in both Canada and Australia did not develop a senior agency or ministerial status within the state at either the central level or the state/provincial level. The statutory authorities that developed during the post war period had a very limited focus on housing production and sought to maintain their independence from broader policy making processes. The branches and later the division in the Australian central government had a similar focus. In both countries the 1970s attempt to develop ministerial departments that placed housing in the broader urban context both failed. So, beneath the surface of both Canadian and Australian governments, which in their public discourse related housing to broader social and economic life, their housing agencies pursued narrow policy objectives. In the past two decades social housing agencies have focussed on developing new management systems associated with managing a limited housing stock and improvements in service provision often to tenant populations that are low income and experience other forms of disadvantage. The broader debates about housing policy are now dominated by central or first minister agencies that see housing policy as a sub-set of economic policy. The outcome therefore is one where state agencies with housing policy and program responsibilities are poorly placed to represent the interests of low income households who are experiencing new and enduring forms of disadvantage within state policy making processes.

\section{Civil society constituencies}

The analysis so far has focussed on the discursive framing of housing problems and the form and nature of state organisation. It has been argued that both these aspects of housing policy make it difficult to formulate an analysis that can sustain a viable policy process and be able to rely on state agencies to present the case within state policy processes. However, it is also important to consider the ways in which non-state, or civil society, actor groups interact with the state in policy making processes around housing issues. It is important to remember that the state does not have clear boundaries and that there is constant interaction between state and non-state actors in all areas of policy making. The metaphor of the 'crossroads state' proposed by Cerny (1990) is useful here. It provides a means for thinking about the way in which the state is a highly permeable structure and provides many sites for the interaction of state and civil society groups in policy making processes. Of course these processes are shaped in very particular ways and it is important to avoid the pluralist assumption and imagine that these crossroads are democratically accessible to all. 
Two principal dimensions in the interaction between state and non-state groups are useful for the analysis: the role of catch-all parties engaged in competitive electoral processes and associations found in sectoral policy networks and communities.

The concept of 'catch all' parties refers to class and other collective identities that have sought to influence the exercise of political power. The ways in which these identities have formed has reflected the social and economic experiences and creativity of various groups (Jenson, 1990, Jessop, 1990). The parties are 'catch-all' because they are parties that where class identities are represented along side of other identities including, citizens, consumers, taxpayers, tenants and home owners and so on, all of which leads to complex trade-offs within the party policy making calculus. Therefore low income people have a relationship with policy making processes through political parties, but it is an attenuated relationship that is de-thematised. This idea is important for the analysis of housing policy and the representation of low income tenants and homeless. Their identity and policy priorities are always in competition with those of many others against a background where party leaders are making judgements about which identities have priority and how they should be represented.

Associations are important because they have become the means through which actors groups deal with the state and each other around state policy. They 'act as governance mechanisms by defining and procuring public goods through organising and enforcing cooperative behaviour among their members, by engaging in collective contracts with other associations, and by securing delegations of state authority to be used to the advantage of their members (Coleman, 1996:129). They do this by ordering and coordinating information and member activities, and managing inter-organisational relations, including relations with state agencies. Typically they will develop will also develop a degree of autonomy from their members and the state. Typically within any one policy area their will be many associations (ibid:129).

In both Canada and Australia catch-all parties and associations have had a long history of involvement in housing policy. Table 2 presents a summary list of the parties and associations with a direct interest in housing policy in both countries. 
Table 2: Catch-all political parties and national associations Australia and Canada

\begin{tabular}{|c|c|c|}
\hline & Main political parties & National associations \\
\hline Australia & $\begin{array}{ll}\text { - } & \text { Australian Labor Party (ALP) } \\
\text { - } & \text { Liberal Party of Australia } \\
\text { - } & \text { Country Party/National Party }\end{array}$ & 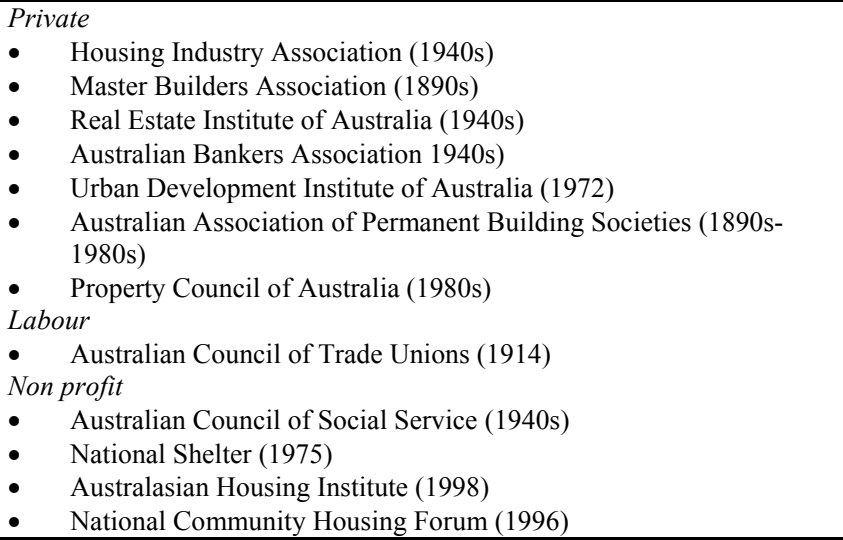 \\
\hline Canada & $\begin{array}{ll}- & \text { Liberal Party } \\
\text { - } & \text { Conservative Party } \\
\text { - } & \text { New Democratic Party }\end{array}$ & $\begin{array}{l}\text { Private } \\
\text { - } \quad \text { Canadian Home Builders Association (1940s) } \\
\text { - } \quad \text { Canadian Bankers Association (1891) } \\
\text { - } \quad \text { Canadian Real Estate Association (1940s) } \\
\text { Labour } \\
\text { - } \quad \text { Canadian Development Institute Canada (1973) } \\
\text { Non profit } \\
\text { - } \quad \text { Cooperative Union of Canada (1901) } \\
\text { - } \quad \text { Community Renewal Housing Association (1968) } \\
\text { - } \quad \text { Cooperative Housing Federation of Canada (1968) } \\
\text { - } \quad \text { (1943) } \\
\text { Local governan Welfional Aboriginal Housing Association } \\
\text { - } \quad \text { Federation of Canadian Municipalities (1901) }\end{array}$ \\
\hline
\end{tabular}

In both Australia and Canada two main observations can be made about the way in which the main stream political parties have engaged with housing issues. First, in terms of their formal policy platforms there has not been a great deal of difference in the policy stances they have taken. In both countries they have not surprisingly supported home ownership. As already discussed both countries are mass home ownership societies and the cultural preference for home ownership is dominant. The political parties have never sought to challenge this deep cultural preference. Consequently party platforms have reflected this in their support for all manner of measures of support. The only difference is between the measure and the extent of support. This does not mean that commitments supporting private rental tenants and social housing tenants are missing. They are present but they are always more limited. Second, there has been a noticeable decline in the prominence that housing issues have received in party political platforms. In the early post war period political parties competed vigorously with their levels of commitment to overcome the shortages and ease the pent up demand. However, more recently the competitive electoral process has focussed less and less on housing issues. As the issues have changed from absolute supply issues to ones of affordability and access the main stream political parties have given the identity of the low income renter a low priority in policy platforms.

Why has this priority slipped? Sewell (1994:11) provides us with a clue when he states: 
No national tenant's organisation who objective is to set national housing policy exists in Canada, as in some European countries, nor are there provincial or national organisations of homeowners or first-time buyers.

Exactly the same observation can be made for Australia. There have been attempts in both countries to form national tenant organisations but they have not endured. In other words in both countries the people who experience disadvantaged in housing markets have not developed a broad enduring national identity able to be recognised in political processes. Instead the experiences of the people who suffer housing market disadvantage are spoken for by others.

The housing policies that do get adopted are worked out informally among the public and private sector players, generally free from direct influence by Canada's many housing consumers (Sewell, 1994:11)

Again the process is the same for Australia. In both countries it is the associations listed in Table 2 that are involved. Further, they are constantly involved by working with their memberships, interacting with each other and with representatives of state agencies. Besides being a day-to-day process it is also a process that has its high points from the point of view of social liberal organisations which might be described as mobilisations.

In the Australia there has only been one significant mobilisation that has resulted in a noted policy change. This occurred in the late 1950s and early 1960 when a wide range of organisations became impatient about the continuing post war housing shortage. Various interest groups mobilised around demands for more housing finance. Initially the campaign was led by a left wing building workers union in collaboration with the Australian Council of Trade Unions. It developed an extensive issue network comprised of other unions, community organisations and peak organisations representing the house building industry, real estate agents and cooperative housing societies ${ }^{6}$. Both major parties supported these demands and wrote this support into their policies. The Liberal Party was particularly important because it underscored and transmitted the demands to the Coalition Government in 1962. This resulted in the establishment of the Housing Loans Insurance Corporation which underwrote the expansion of housing finance a further expansion of home ownership and largely met the demands of the groups.

This episode contrasted with one played out in the late 1980s and 1990s that had two features. This was a period when the case for the deregulation of the finance system, initially proposed by the Committee of Inquiry into the Australian Financial System (Campbell Inquiry) (1981), was well advanced. Initially both political parties continued to represent the interests of intending purchasers described for them by industry organisations and social liberal peak associations by supporting direct assistance programs. However, within each party there was debate and these proposals were undermined by others pursuing other economic policy agendas. Housing policy became marginal within in the mainstream national political parties. Second, as the finance system was deregulated industry and social liberal peak organisations and sections of the union movement sought to develop new finance measures which tapped into the pool of superannuation savings resulting from new measures introduced in the late 1980s. These groups argued for state support for the development of a secondary mortgage market and housing bonds which would direct funds to low income purchasers and to social housing. These proposals 
although canvassed were opposed by the Treasury and the Labor government core executive. The defeat failed to produce any broad mobilisation or other effective counter response.

The processes in Canada have been a little different. Overall it suggests a higher degree of mobilisation by civil society social liberal organisations.

The first episode that suggests a difference is the expansion of public housing from 1964. From the late 1950s there had been a decrease in housing affordability for the lowest income households (Hulchanski, 1993). There had also been a temporary decline in house starts during 1956 and 1957 and they declined again in the early 1960s. In other words there was instability in housing production processes. Also there were changes in the housing industry that were disadvantaging smaller builders. This is the context that social liberals pushed their case for expanding the public housing program. However, it was difficult as Carver (1975:160) explained because "we have not had a strong national organisation to speak for those in serious housing need ... there has not been a lobby for overcoming the inequities of housing. Consequently housing debates in Parliament and the provincial legislatures have been lamentably weak'. The case rested on the arguments put by a network of social liberals in universities and welfare organisations. What made the difference particularly in a context where there had been such strong opposition from the Department of Finance? Four factors are identified by Chouinard (1986). First, she notes uncertainty amongst officials that they could establish industry stability through finance measures alone. Second, she argues that social liberals did organise and press their case more vigorously. Certainly this was the case by the end of the 1960s with the holding of the 'first Canadian Conference on Housing' (Wheeler, 1969). Third, provincial governments were transmitting pressure for public housing. This was coming from city and provincial social welfare groups but also from other interests in the cities who saw public housing as a means for overcoming limited investment in central city areas. Fourth, she notes a general increase in labour militancy which an increase in social programs might be seen as a suitable response.

But perhaps more significant is the expansion of non-profit and cooperative housing from the mid 1970s. Again this is a time of instability in the housing industry evident in Figure 5. Also it was a period of declining housing affordability due to inflation and underlying increases in the costs of land and housing production. Again it was a period of considerable labour unrest (Chouinard, 1986). However, the case for a social housing response was stronger. Social liberals had been influential through the Task Force on Low Income Housing (HellyerTask Force) (1972) and the Dennis and Fish (1972) inquiry. These reports presented a critique of public housing and a case for non public housing social housing as an alternative. Beyond this there was a much more substantial mobilisation of community based organisations. They were represented through the Canadian Council for Social Development and Community Renewal Housing Association. Also other community groups, the student movement and the peace movement mobilised through the cooperative movement and were presenting their case through the newly formed Cooperative Housing Federation of Canada. This is the context within which 'officials sought for alternative forms of assisted housing which could serve people eligible for public housing, that could provide shelter for moderate income households that could no longer afford owner-occupation and help control state expenditures'(Chouinard, 1986:137). Non-profit housing and cooperatives were attractive because the costs could be contained by devolving responsibility and there were possible savings through volunteer labour and sweat equity. This is 
the process that led to a decade of sustained funding to social housing provided by civil society organisations. It is a form of organisation and mobilisation that has never been present in the Australian context.

In sum, in both Canada and Australia the political parties have been important in transmitting housing issues and policy ideas into government. However this role has diminished. Housing policy is not a subject of policy competition in the way that it was in the post war period. Political parties do not recognise the identity of the low income renter or homeless person and respond with policy and program proposals. In the current context the housing market affordability and insecurity problems of low income earners are only evident at the national level in the representations of social liberal research and advocacy. In the past there has been some mobilisation around the issues through civil society organisations which has been represented through national associations. In Australia this has largely focussed on improving home ownership finance. Associations advocating additional public housing or other forms of social housing have made little impact over nearly two decades. In Canada civil society organisations have mobilised and have been successful on two occasions in brokering a social housing response. On the first occasion this was delivered through the state. On the second occasion it was delivered through non-profit organisations and cooperatives. Like Australia these groups have made little headway in achieving a supply response over the past decade.

\section{Conclusion}

This paper has sought to answer the question 'Why has housing policy retrenchment occurred at the same time as accepted measures show increased housing need?' in both Canada and Australia. They are two mass homeownership countries where changing social and economic conditions have resulted in a significant proportion of households experiencing new and intensive forms of housing market disadvantage. Further, there is evidence that this disadvantage is due to structural changes including those in the housing and labour markets, in income distribution and demographic change. A general argument that is sometimes invoked is that the policy environment has changed. Economic liberalism has become the dominant paradigm and replaced the Keynesian policy infused with social liberal measures. I have argued that this is not a sufficient explanation. Welfare states have not become any smaller. Canada and Australia provide no exceptions.

It is therefore important to extend the search for what might be causing this lack of response to new forms of housing market disadvantage. The paper sought to do this by examining three features of housing policy making: housing policy discourse, state agency arrangements and civil society constituencies and mobilisations. The argument drawn from the discussion of housing policy discourse is that it is limited by the dominant focus on housing production. Social liberal influences have been limited. It is important to further develop this discourse by demonstrating that the implications of changing housing market conditions are having effects that disadvantage more than the lowest income households. Research and advocacy remain important undertaken against a background of understanding of the full range of contributions from within state agencies and other interests, particularly producer interests. The development of state agencies has limited the response to changing housing needs. Housing agencies in state policy making processes tend to have a low status and are marginalised by first minister or central agencies, particularly economic policy central agencies. This suggests that there is a case for establishing a 
broader frame of reference seeks to make connections with a broader range of agencies, particularly in a context where cities are more exposed to global economic processes. Civil society processes focussed on housing issues and solutions have been important in the development of housing policy. They have made a difference particularly when there has been a degree of mobilisation and the development of alliances. They have resulted from creative work by activists which can be repeated.

1 Irrespective of tenure the overall quantity of housing in New Urban Frontier cities was considerably higher than in cities based on the old economy. The figures below indicate that Australian cities had more housing than did Canadian cities but that they were grouped together.

Australian and Canadian cities: dwellings per 100 persons, 1870 - 1910 (ranked in 1910)

\begin{tabular}{|c|c|c|c|c|c|}
\hline & 1870 & 1880 & 1890 & 1900 & 1910 \\
\hline Adelaide & 20.5 & 19.4 & 20.4 & 21.4 & 21.0 \\
\hline Perth & $*$ & $*$ & $*$ & 19.8 & 20.5 \\
\hline Melbourne & * & 18.2 & 19.1 & 19.3 & 20.2 \\
\hline Sydney & $*$ & 18.6 & 17.9 & 17.9 & 19.6 \\
\hline Toronto & 17.4 & 19.5 & 20.0 & 18.5 & 18.5 \\
\hline Vancouver & $*$ & 14.7 & 19.9 & 20.7 & 17.3 \\
\hline Montreal & 15.0 & 16.2 & 17.5 & 18.0 & 15.9 \\
\hline Winnipeg & $*$ & 15.9 & 17.7 & 17.8 & 15.5 \\
\hline
\end{tabular}

Source: Frost, L. (1991).

2 Available comparative evidence suggests that access to homeownership became more difficult for low income Canadian households considerably earlier than it did for low income Australian households. Hulchanski, (1993). notes a drop in the ownership rate of Canadian households in the lowest quintile from 62 per-cent to 50 per-cent between 1967 and 1973 and further declines to 47 per-cent in 1977 and 43 per-cent in 1981. Comparable data presented by Bethune (1978) indicates a rate between 58 and 62 per-cent for the lowest quintile in 1966-67. In the early 1970s (1973-75), depending on the data source, the rate was between 53 per-cent and 67 per-cent. In others words entry of low income Canadian households into home ownership appears to have become considerably more difficult than it did for low income Australian households during the late 1960s and early 1970s.

3 Decline in the level of unemployment in both countries in the last few years has contributed to a decline in total expenditures because the demand for assistance to the unemployed as decreased. This is evident in the figure where the trend lines are very similar. However, in both Canada and Australia there has been an overall increase. Further, in Australia the reduction in expenditure on unemployment benefits does not provide any explanation of the steady increase in Australian social expenditures as a proportion of GDP in the period since 1988 shown in Figure 7. 


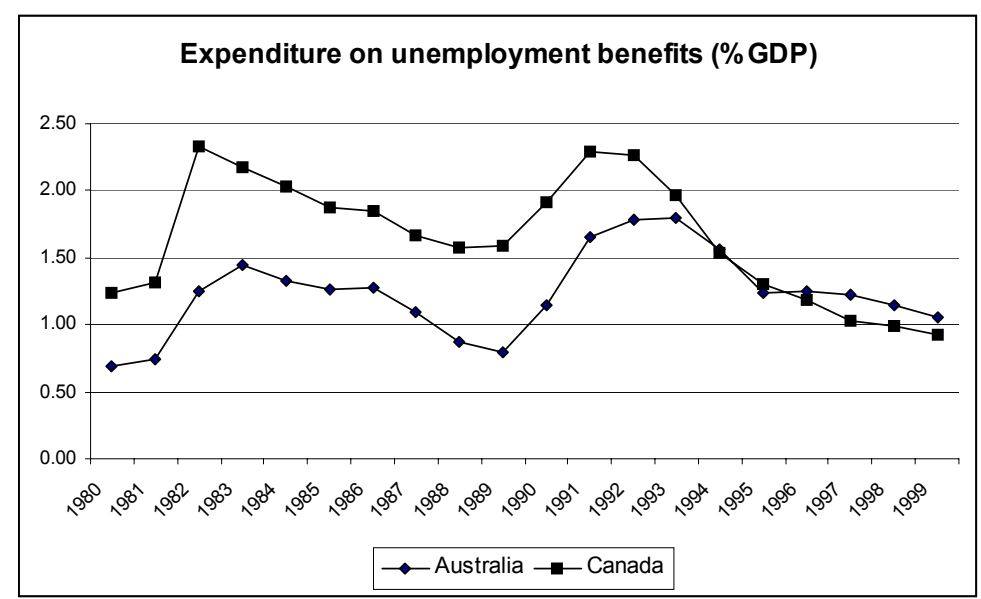

4 The Australian Housing Corporation was barely established before it was abolished following the defeat of the Whitlam Labor Government by a conservative Liberal-National Party Coalition Government in 1975. It was intended that it would become a major new lender and focus particularly on the low and moderate income households.

5 It is important to note that the War Service Homes Commission was established at the end of WWI. It became a major mortgage lender to returned service men. This role was expanded considerably in the post WWII period. It maintained a great deal of autonomy for many years.

6 Cooperative housing societies in the Australian context were initially small local neighbourhood committees, often drawn from the professions, which distributed housing loans to young couple households that had put their names on a waiting list. The housing finance was made available at fixed interest rates by the state owned banks. This neighbourhood form of organisation and mortgage retailing can be seen as a cultural and economic practice that assisted households to become homeowners while further deepening a belief in home ownership.

\section{Bibliography}

Advisory Committee on Reconstruction (1944) Final Report of the Sub-committee on Housing and Community Planning, King's Printer, Ottawa.

Bacher, J. C. (1993) Keeping to the Marketplace: The Evolution of Canadian Housing Policy, McGillQueen's University Press, Montreal and Kingston.

Beer, A. (1993) “'A Dream won, a crisis born”' in Ed, Paris, C., Housing Australia, Macmillan, Melbourne.

Belec, J. (1984) 'Origins of state housing policy in Canada: the case of the Central Mortgage Bank', The Canadian Geographer, Vol.28, No.4, pp.377-82.

Bell, S. (1997) Ungoverning the economy: the political economy of Australian economic policy, Oxford University Press, Melbourne.

Berry, M. (1988) 'To Buy or Rent?: The Demise of a Dual Tenure Policy 1945-60' in Ed, Howe, R., New Houses for Old: Fifty Years of Public Housing in Australia 1938-1988, Ministry of Housing and Construction, Melbourne.

Berry, M. (1998) 'Investment in Rental Housing in Australia: Small Landlords and Institutional Investors', European Network for Housing Research Conference, Cardiff, Wales, 
Berry, M. and Dalton, T. (2004) 'Housing Prices and Policy Dilemmas: A Peculiarly Australian Problem?' Urban Policy and Research, Vol.22, No.1, pp.69-91.

Bethune, G. (1978) Home-ownership in Australian capital cities, with particular reference to Sydney and Melbourne, Degree of Doctor of Philosophy, Australian National University, Canberra

Bourne, L. S. (1993) 'The Changing Settlement Environment of Housing' in Ed, Miron, J. R., House, Home, and Community: Progress in Housing Canadians, 1945-1986, McGill-Queens University Press and Canada Mortgage and Housing Corporation, Montreal and Ottawa.

Bradford, N. (2000) 'The Policy Influence of Economic Ideas: Interests, Institutions and Innovation in Canada' in Eds, Burke, M., Mooers, C. and Shields, J., Restructuring and Resistance: Canadian Public Policy in an Age of Global Capitalism, Fernwood Publishing, Halifax, Nova Scotia.

Burke, M. and Shields, J. (2000) 'Tracking Inequality in the New Canadian Labour Market' in Eds, Burke, M., Mooers, C. and Shields, J., Restructuring and Resistance: Canadian Public Policy in an Age of Global Capitalism, Fernwood Publishing, Halifax, Nova Scotia.

Campbell, I. (1997) 'The Challenge of Increased Precarious Employment', Just Policy, No.11, December, pp.4-20.

Canada Mortgage and Housing Corporation (2002) Canada's Housing System, Canada Mortgage and Housing Corporation, Ottawa,

Capling, A. and Galligan, B. (1992) Beyond the protective state: the political economy of Australia's manufacturing industry policy, Cambridge University Press, Melbourne.

Carter, T. (2004) 'Canadian Housing Prices: the Road to Wealth?' Urban Policy and Research, Vol.22, No.1, pp.35-48.

Carver, H. (1975) Compassionate Landscape, University of Toronto Press, Toronto.

Cerny, P. (1990) The Changing Architecture of Politics: Structure, Agency, and the Future of the State, Sage, London.

Chouinard, V. (1986) State Formation and Housing Policies: Assisted Housing Programmes and Cooperative Housing in Postwar Canada, Doctor of Philosophy, McMaster University, Montreal

Cockett, R. (1995) Thinking the Unthinkable: Think-Tanks and the Economic Counter Revolution, Harper Collins, London.

Coleman, W. D. (1996) 'Associational governance in a globalising era: weathering the storm' in Eds, Hollingsworth, J. R. and Boyer, R., Contemporary Capitalism: The Embeddedness of Institutions, Cambridge University Press, New York.

Comission of Inquiry into Poverty (1975) Poverty in Australia, First Main Report Australian Government Publishing Service, Canberra.

Committee of Inquiry into the Australian Financial System (Campbell Inquiry) (1981) Final Report, Australian Government Publishing Service, Canberra.

Commonwealth Housing Commission (1944) Final Report, Government Printer, Sydney.

Crook, T. (1998) 'The supply of private rented housing in Canada', Netherlands Journal of Housing and the Built Environment, Vol.13, No.3, pp.327-352.

Dalton, T. (1988) 'Architects, Engineers and Rent Collectors: An Organisational History of the Commission' in Ed, Howe, R., New Houses for Old: Fifty Years of Public Housing in Victoria, Ministry of Housing and Construction, Melbourne.

Dalton, T. (2002) 'Which way housing policy? Housing markets and policy agendas', Just Policy, No.25, pp.3-12.

Dennis, M. and Fish, S. (1972) Programs in Search of Policy: Low Income Housing in Canada, A. M. Hakkert, Toronto.

Downing, R. I. (1948) 'Housing and Public Policy’, Economic Record, Vol.24, No.June, pp.72-86.

Dunk, W. E. (1950) 'Letter to Rt. Hon. R.G. Casey, Minister for Works and Housing', Department of National Development-Creation of Department, Series A451/1 Item 51/367, Australian Archives, Canberra. 
Fallis, G. (1994) 'The Federal Government and the Metropolitan Housing Problem' in Ed, Frisken, F., The Changing Canadian Metropolis: A Public Policy Perspective, Institute of Governmental Studies Press and Canadian Urban Institute, Berkley and Toronto.

Firestone, O. J. (1943) The Labour Value of the Building Dollar, Housing Administration, Department of Finance King's Printer, Ottawa.

Flood, J. and Yates, J. (1987) Housing Subsidies Study, Australian Government Publishing Service, Canberra.

Franzway, S., Court, D. and Connell, R. W. (1989) Staking a claim: Feminism, bureaucracy and the state, Allen and Unwin, Sydeny.

Freestone, R. (1989) Model Communities: the Garden City Movement in Australia, Thomas Nelson, Melbourne.

Frost, L. (1991) The New Urban Frontier: Urbanisation and City-building in Australasia and the American West, New South Wales University Press, Sydney.

Hall, J. and Berry, M. (2004) Operating deficits and public housing: policy options for reversing the trend, Australian Housing and Urban Research Institute, Melbourne, www.ahuri.edu.au

Hall, P. (1989) 'Conclusion: The Politics of Keynesian Ideas' in Ed, Hall, P., The Political Power of Economic Ideas: Keynsianism across Nations, Princeton University Press, Princeton.

Harloe, M. (1995) The People's Home?: Social Rented Housing in Europe and America, Blackwell, Oxford.

Harris, R. (1996) Unplanned Suburbs: Toronto's American Tragedy, 1900-1950, The Johns Hopkins University Press, Baltimore, USA.

Hulchanski, J. D. (1993) 'New Forms of Owning and Renting' in Ed, Miron, J. R., House, Home, and Community: Progress in Housing Canadians 1945-1986, Canada Mortgage and Housing Corporation, Ottawa, McGill-Queen's University Press, Montreal.

International Labour Office (1948) Housing and Employment, Studies and Reports, New Series, No. 8 International Labour Office, Geneva.

Inwood, G. J. (2000) 'Federalism, Globalisation and the (Anti-)Social Union' in Eds, Burke, M., Mooers, C. and Shields, J., Restructuring and Resistance: Canadian Public Policy in an Age of Global Capitalism, Fernwood Publishing, Halifax, Nova Scotia.

Jackson, R. and Bridge, H. (1987) 'Housing' in Eds, Gaff, J., Lanagan, M. and Thompson, R., Australians, Historical Statistics, Fairfax, Syme and Weldon Associates, Sydney.

Jenson, J. (1989) ' Different' but not 'exceptional': Canada's permeable fordism', Canadian Review of Sociology and Anthropology, Vol.26, No.1, pp.69-94.

Jenson, J. (1990) 'Representations in Crisis: The Roots of Canada's Permeable Fordism', Canadian Journal of Political Science, Vol.24, No.3, pp.653-683.

Jessop, B. (1990) State Theory: Putting Capitalist States in Their Place, Pennsylvania State University Press.

Jones, M. (1972) Housing and Poverty in Australia, Melbourne University Press, Melbourne.

Linklater, J. (1992) Inside the Bank: The Role of the Reserve Bank of Australia in the Economic, Banking and Financial Systems, Allen and Unwin, Sydney.

Lithwick, N. H. (1970) Urban Canada: problems and prospects, Central Mortgage and Housing Corporation, Ottawa.

Lloyd, D. D. and Troy, P. N. (1981) Innovation and Reaction: The Life and Death of the Federal Department of Urban and Regional Development, George Allen and Unwin, Sydney.

Mahon, R. (1977) 'Canadian public policy: the unequal structure of representation' in Ed, Panitch, L., The Canadian State: Political Economy and Political Power, University of Toronto Press, Toronto.

Marsden, S. (1986) Business, Charity and Sentiment: The South Australian Housing Trust 1936-1986, Wakefield Press, Adelaide.

Marsh, L. (1943) Report on Social Security for Canada, Toronto University Press, Toronto. 
Mathews, R. L. and Grewal, B. S. (1997) The public sector in jeopardy : Australian fiscal federalism from Whitlam to Keating, Centre for Strategic Economic Studies, Victoria University, Melbourne.

McQuaig, L. (1999) The Cult of Impotence: Selling the Myth of Powerlessness in the Global Economy, Penguin Books, Toronto.

Mendelsohn, R. and Hamilton, J. M. (1948) 'The Australian Housing Cost Index', Economic Record, Vol.24, No.June, pp.87-100.

Miron, J. R. (1988) Housing in Postwar Canada, McGill-Queens University Press, Kingston and Montreal.

Mishra, R. (1990) 'The Collapse of the Welfare Consensus? The Welfare State in the 1980s' in Eds, Fallis, G. and Murray, A., Housing the Homeless and Poor: New Partnerships among the Private, Public and Third Sectors, University of Toronto Press, Toronto.

Mitchell Evans, B., McBride, S. and Shields, J. (2000) 'Globalisation and the Challenge to Canadian Democracy: National Governance Under Threat' in Eds, Burke, M., Mooers, C. and Shields, J., Restructuring and Resistance: Canadian Public Policy in an Age of Global Capitalism, Fernwood Publishing, Halifax, Nova Scotia.

Neutze, M. (1977) Urban Development in Australia, George Allen and Unwin, Sydney.

OECD (2000) OECD Social Expenditure Database, OECD, Paris, http://www.oecd.org/home/

Pauly, L. (1987) Foreign Banks in Australia: The Politics of Deregulation, Australian Professional Publications in association with the Centre for Money, Banking and Finance, Macquarie University, Sydney.

Pomeroy, S. (2001) Toward a Comprehensive Affordable Housing Strategy for Canada, The Caledon Institute of Social Policy, Ottawa.

Pomeroy, S. (2003) Background Context (1998) and Various Policy Updates on the Canadian Housing System, Focus Consulting Inc, Ottawa,

Priorities Review Staff (1975) Report on Housing, Australian Government Publishing Service, Canberra.

Pugh, C. (1976) Intergovernmental relations and the development of Australian housing policies, Research Monograph No.15 Centre for Research on Federal Financial Relations, The Australian National University, Canberra.

Purdy, S. (1998) 'Building homes, building citizens: Housing reform and nation formation in Canada, 1900-20', Canadian Historical Review, Vol.79, No.3, pp.492-523.

Rice, J. and Prince, M. (2000) Changing Politics of Canadian Social Policy, University of Toronto Press, Toronto.

Rose, A. (1980) Canadian Housing Policies, Butterworth, Scarborough, Ontario.

Royal Commission appointed to inquire into the Monetary and Banking Systems at present in operation in Australia (1937) Report, Commonwealth Government Printer, Canberra.

Royal Commission on the Economic Union and Development Prospects for Canada (1985) Report, Supply and Services Canada, Ottawa.

Saward (1997) 'In Search of the Hollow Crown' in Eds, Weller, P., Bakvis, H. and Rhodes, R. A. W., The Hollow Crown: Countervailing Tends in Core Executives, Macmillan Press, London.

Senate Select Committee on Superannuation (1994) Super for Housing, Twelfth Report of the Senate Seclect Committee on Superannuation Senate Printing Unit, Parliament House, Canberra.

Sewell, J. (1994) Houses and Homes: Housing for Canadians, James Lorimer \& Company, Toronto.

Smeeding, T. (2000) Changing Income Inequality in OECD Countries: Updated Results from the Luxembourg Income Study, Luxembourg Income Study Working Paper No. 252., Center for the Study of Population, Poverty and Public Policy (CEPS)/International Networks for Studies in Technology, Environment, Alternatives, Development (INSTEAD), http://www.lisproject.org/publications/wpapersf.htm, 
Spooner, W. H. (1954) 'Letter to Prime Minister R.G. Menzies, 22nd June', [Menzies Papers] correspondence with [mostly] W.H. Spooner, Minister for National Development, Series M257611 Item 4, Australian Archives, Canberra.

Steele, M. (1993) 'Incomes, Prices, and Tenure Choice' in Ed, Miron, J. R., House, Home and Community: Progress in Houisng Canadians, 1945-1986, Mcgill-Queen's University Press, Montreal, Canada Mortgage and Housing Corporation, Ottawa.

Task Force on Low Income Housing (1972) Report of the Task Force on Low Income Housing, Central Mortgage and Housing Corporation, Ottawa.

TD Bank Financial Group (2003) Affordable housing in Canada: In search of a new paradigm, TD Economics Special Report, www.td.com/economics.

Toohey, B. (1994) Tumbling Dice: The Story of Modern Economic Policy, William Heineman Australia, Melbourne.

Wanna, J. (1997) 'Managing Budgets' in Eds, Weller, P., Bakvis, H. and Rhodes, R. A. W., The Hollow Crown: Countervailing Tends in Core Executives, Macmillan Press, London.

Watts, R. (1987) 'Family allowances in Canada and Australia 1940-1945: A comparative critical case study', Journal of Social Policy, Vol.16, No.1, pp.19-48.

Wheeler, M. (Ed.) (1969) The right to housing, Harvest House, Montreal.

Whitwell, G. (1986) The Treasury Line, Allen and Unwin, Sydney.

Wolfe, J. M. and Jay, W. (1990) 'The Revolving Door: Third-Sector Organisations and the Homeless' in Eds, Fallis, G. and Murray, A., Housing the Homeless and Poor: New Partnerships among the Private, Public and Third Sectors, University of Toronto Press, Toronto.

Yates, J. (1998) Trends in Home Ownership, report to NSW Department of Housing, Sydney.

Yates, J. (2000) 'Is Australia's Home Ownership Rate Really Stable? An Examination of Change Between 1975 and 1994', Urban Studies, Vol.37, No.2, pp.319-342.

Yates, J. and Wulff, M. (2000) 'W(h)ither Low Cost Private Rental Housing?' Urban Policy and Research, Vol.18, No.1, pp.45-64. 